\title{
ŻOŁNIERZ I SŁUŻBA WOJSKOWA W ŚWIETLE KOŚCIELNYCH ŹRÓDEL NORMATYWNYCH Z IV I V WIEKU
}

Na początku IV w. sytuacja prawna chrześcijan w Imperium Rzymskim uległa diametralnej zmianie. Za sprawą cesarza Konstantyna przestali być prześladowani i uzyskali status religio licita ${ }^{1}$. Od tego momentu poglądy chrześcijan na państwo zaczęły ewoluować. Był to proces długofalowy i nie wszędzie występował z taką samą dynamiką. Jednym z aspektów tej transformacji była zmiana stosunku chrześcijan do służby wojskowej. Wystarczy sięgnąć do już klasycznych pozycji Adolfa Harnacka (7 V 1851 - 10 VI 1930)² czy Johna C. Cadoux (1883 - 16 VIII 1947)3, by się przekonać, że współcześni

${ }^{*}$ Mgr Andrzej Hołasek - doktorant przy Katedrze Historii Bizancjum w Instytucie Historii na Wydziale Filozoficzno-Historycznym Uniwersytetu Lódzkiego; e-mail: aholasek@onet.eu.

${ }^{1}$ Temat nawrócenia się Konstantyna i zmiany polityki państwa rzymskiego wobec chrześcijan na przestrzeni ostatnich dziesięcioleci został omówiony w ogromnej liczbie publikacji. Z konieczności odwołuję się tylko do kilkunastu wybranych: A. Alföldi, The Conversion of Constantine and Pagan Rome, thum. H. Mattingly, Oxford 1948, passim; R. MacMullen, Constantine, London 1969, 55183; M. Simon, Cywilizacja wczesnego chrześcijaństwa. I-IV w., tłum. E. Bąkowska, Warszawa 1979, 221-228; W. Ceran, Kościót wobec antychrześcijańskiej polityki cesarza Juliana Apostaty, Acta Universitatis Lodziensis. Seria I, nr 63, Łódź 1980; T.D. Barnes, Constantine and Eusebius, Cambridge 1981; A. Młotek, Postawy i świadectwa. Kościót wobec problemów moralnych IV wieku, Wrocław 1986, 131-143; E. Wipszycka, Kościót w świecie późnego antyku, Warszawa 1994, 135163; H.A. Drake, Constantine and the Bishops. The Politics of Intolerance, Baltimore - London 2000, 187-272; H. Chadwick, Kościót w epoce wczesnego chrześcijaństwa, thum. A. Wypustek, Warszawa 2004, 124-135; H.A. Drake, The Impact Constantine on Christianity, w: The Cambridge Companion to the Age of Constantine, ed. N. Lenski, Cambridge 2006, 111-136; T. Wnętrzak, Konstantyn Wielki w oczach Euzebiusza z Cezarei $i$ w badaniach współczesnych historyków, w: Euzebiusz z Cezarei, Życie Konstantyna, tłum. taż, ŹMT 44, Kraków 2007, 9-96; P. Chuvin, Ostatni poganie, tłum. J. Stankiewicz-Prądzyńska, Warszawa 2008, 35-48; S. Bralewski, Cesarz Konstantyn I Wielki wobec kontrowersji ariańskiej, „Labarum” VIII, Poznań 2009; P. Veyne, Poczatki chrześcijańskiego świata (312-394), thum. I. Kania, Warszawa 2009, 59-114; S. Bralewski, Życie religijne mieszkańców Konstantynopola, w: Konstantynopol. Nowy Rzym, red. M.J. Leszka T. Wolińska, Warszawa 2011, 401-427.

${ }^{2}$ Por. A. Harnack, Militia Christi. Die christliche Religion und der Soldatenstand in den ersten drei Jahrhunderten, Tübingen 1905, passim.

${ }^{3}$ Por. J.C. Cadoux, The Early Christian Attitude to War. A Contribution to the History of Christian Ethics, The Christian Revolution Series, London 1919, passim. 
uczeni zajmują się tym problemem od dawna. Jednakże należy się zgodzić z Alanem Kreiderem, że w niewielkim stopniu przestudiowano zapisy kościelnych źródeł normatywnych. On sam zgłębił kilka wybranych dzieł o charakterze normatywnym z III i IV w. i opisał zmiany, jakie pojawiały się w treści przepisów kościelnych, na przestrzeni tych dwóch stuleci ${ }^{4}$. Jednakże jego ustalenia nie wyczerpały problemu badawczego, ponieważ mamy do czynienia ze specyficzną i dość obszerną grupą źródeł, w której oryginały oraz przeredagowane wersje, powstawały pomiędzy II a VI wiekiem. Ewa Wipszycka słusznie zwróciła uwagę na wyzwania, które wiążą się z badaniem kościelnych źródeł normatywnych. Po pierwsze, należy pamiętać, że ich treść stanowiła ideał, do którego ówcześni chrześcijanie powinni dążyć. Po drugie, przepisy różnej natury i proweniencji często umieszczano w jednym utworze, kolekcji czy rękopisie. Po trzecie, przepisy powstałe w jednym regionie wielokrotnie przyswajano gdzie indziej, choć ich odpisy lub tłumaczenia mogły się znacząco różnić od oryginału. Po czwarte, autorstwo niektórych dzieł normatywnych przypisywano apostołom lub ich bezpośrednim uczniom, przez co zaliczamy je do grupy utworów pseudoepigraficznych. Natomiast brak szczegółowej wiedzy na temat ich autora i miejsca powstania nie pozwala na precyzyjne określenie czasu spisania ${ }^{5}$. Świadomy powyższych trudności, postanowiłem w niniejszym artykule przybliżyć treść wybranych kościelnych źródeł normatywnych, w których znajdujemy odniesienie do kwestii służby wojskowej dla IV i V w. Prócz omówienia przepisów z poszczególnych dzieł i kolekcji, odnoszę się również do treści kanonów synodów i soborów ze wspomnianego okresu, gdyż zaliczają się one do tej samej grupy źródeł ${ }^{6}$. Wspomniane przepisy interesują mnie z powodu dostosowywania prawodawstwa kościelnego do nowej sytuacji, w której państwo rzymskie przestało być prześladowca, a stało się protektorem chrześcijaństwa.

1. Chrześcijańscy żołnierze przed przełomem konstantyńskim. Nie ulega wątpliwości, że w ciagu trzech pierwszych stuleci chrześcijanie służyli w armii rzymskiej. Początkowo ich liczba była stosunkowo niewielka, ale wraz z postępem ewangelizacji zaczęła wzrastać ${ }^{7}$. Stosunek chrześcijan do

\footnotetext{
${ }^{4}$ Por. A. Kreider, Military Service in the Church Orders, ,Journal of Religious Ethics” 31 (2003) 415-442.

${ }^{5}$ Por. E. Wipszycka, Źródła normatywne kościelne. Wprowadzenie, w: Chrześcijaństwo u schyłku starożytności, t. 5, red. T. Derda - E. Wipszycka, Kraków 2005, 301-344. Wprowadzenie Ewy Wipszyckiej jest najbardziej kompetentnym omówieniem w języku polskim problematyki źródeł, na których koncentruje się treść niniejszego artykułu.

${ }^{6}$ Por. tamże, s. 323-338.

${ }^{7}$ Por. A.G. Hamman, Życie codzienne pierwszych chrześcijan (95-197), tłum. A. Guryn U. Sudolska, Warszawa 1990, 72-75; G. Minois, Kościót i wojna. Od czasów Biblii do ery atomowej, thum. A. Szymanowski, Warszawa 1998, 44-48. Ramsay MacMullen (Soldier and Civilian in Later Roman Empire, Harvard Historical Monographs 52, Cambridge (Mass.) 1963, 155-157
} 
służby wojskowej daleki był od jednomyślności. Poglądy ówczesnych myślicieli chrześcijańskich, niejednokrotnie były wyrazem ich subiektywnej interpretacji, bądź też reprezentowały stanowisko lokalnego Kościoła. Zdarzało się również, że były podyktowane aktualnymi wydarzeniami lub sporami, które toczyły się wokół tej kwestii ${ }^{8}$. Jednakże do początku IV w. przeważnie uznawano, że profesji żołnierskiej nie należy polecać chrześcijanom9. Należy podkreślić, że zawód żołnierza nie cieszył się wówczas w społeczeństwie rzymskim dużym poważaniem. Legioniści i żołnierze wyższej rangi byli powszechnie postrzegani, jako pijacy, rozpustnicy i grabieżcy ${ }^{10}$. Jednakże wśród chrześcijan opór budziły pogańskie rytuały związane ze służbą w armii ${ }^{11}$ oraz

i 176) zauważył, że Septymiusz Sewer (11 IV 145/146 - 4 II 211; cesarz od 9 IV 193), dążąc do promowania w społeczeństwie służby wojskowej, zmniejszył bariery w dostępie ludności cywilnej do kariery w armii oraz poszerzył zakres zadań wojskowych, które obejmowały też cywilne formy służby, np. w charakterze posłańców, odźwiernych, księgowych lub przy budowie dróg itp. Niewykluczone, że pozwalało to niektórym chrześcijanom pogodzić służbę w wojsku z własnym sumieniem i dlatego ich liczba w nim wzrosła. Por. też: M. Cary - H.H. Scullard, Dzieje Rzymu. Od czasów najdawniejszych do Konstantyna, thum. J. Schwakopf, t. 2, Warszawa 1992, 300-306; Minois, Kościót i wojna, s. 47-48.

${ }^{8}$ Por. Minois, Kościót i wojna, s. 46-47; Kreider, Military service, s. 417.

${ }^{9}$ Por. Hamman, Życie codzienne pierwszych chrześcijan, s. 75; Minois, Kościót i wojna, s. 50.

${ }^{10}$ Georges Minois (Kościót $i$ wojna, s. 45-46) wyjaśnia, dlaczego się tak działo. Służba trwała długo, najczęściej około dwudziestu lat. Ponieważ była ochotnicza, zaciągali się do niej najczęściej mężczyźni z nizin społecznych. Żołnierzy obowiązywał zakaz zawierania związków małżeńskich, zatem często korzystali z usług prostytutek lub posiadali konkubiny. Żołd był niski, a życie obozowe pozbawione urozmaicenia i rozrywek. W IV w. werbowani byli barbarzyńcy z nadgranicza, a podczas przenoszenia oddziałów dochodziło do stosowania przez wojsko przemocy wobec ludności i wymuszania zakwaterowania. Por. A. Świętoń, Przymusowy kwaterunek wojskowy w IV i V w n.e. $i$ zwiazane z nim nadużycia, w: Contra leges et bonos mores. Przestępstwa obyczajowe w starożytnej Grecji i Rzymie, red. H. Kowalski - M. Kuryłowicza, Lublin 2005, 343-350.

${ }^{11}$ Żołnierze rzymscy składali przysięgę wierności wobec cesarza, tzw. sacramentum. Jej treść odwoływała się do oficjalnego panteonu bogów. Oficerowie brali udział w składaniu ofiar w celu zapewnienia opieki bóstw w czasie walki. Ponadto armia uczestniczyła w oficjalnych uroczystościach cesarskich, państwowych świętach publicznych i świętach o charakterze czysto wojskowym. W każdym obozie wojskowym znajdowało się aedes principiorum, czyli centralne sanktuarium, w którym przechowywano posagi głównych bóstw państwowych: Jupitera, Junony, Minerwy, Marsa i Wiktorii. Obok nich stały popiersia deifikowanych cesarzy oraz symbole wojskowe. Na terenie obozu znajdowały się również ołtarze i mniejsze świątynie bogów popularnych wśród żołnierzy, których kult miał charakter nieoficjalny. Żołnierze obchodzili święta związane z kultem ubóstwionych cesarzy oraz aktualnie panującego władcy. Czczono dzień narodzin imperatora (dies natalis) oraz rocznice objęcia przez niego tronu (dies imperii). W armii rzymskiej istotną rolę odgrywał także kult symboli wojskowych, tzw. signa. Miał on służyć umacnianiu integralności oddziałów. Najważniejszym z nich była Aquila, wykonany ze srebra orzeł, trzymający w szponach złote atrybuty Jowisza. Uosabiał on opiekę naczelnego boga rzymskiego panteonu nad armią. Prócz tego każdy legion posiadał własne signum (znak, symbol) oraz vexillum (rodzaj proporca). W armii obchodzono specjalne święto Rosalia signorum, podczas którego dekorowano symbole wojskowe różami. Por. A.D. Nock, The Roman Army and the Roman Religious Year, HTR 45 (1952) 187-252; 
przelewanie krwi podczas walki. Na początku III w. na temat służby wojskowej głos zabrał Tertulian (ok. 150 - ok. 220). Jego poglądy w tej sprawie były bardzo złożone i z czasem ewoluowały. Pisarz rozgraniczał sytuacje, kiedy żołnierz zostawał chrześcijaninem, od tej, gdy chrześcijanin chciał wstapić do armii. W pierwszym wypadku pozwalał na kontynuowanie służby, choć przede wszystkim nakazywał unikać wszelkich przejawów bałwochwalstwa. W drugim zabraniał podjęcia służby wojskowej. W swoich dziełach De idolatria $^{12}$ oraz De corona ${ }^{13}$ argumentował, że chrześcijanin nie może pogodzić służby w armii z posłuszeństwem Bogu. Wiemy, że obydwa traktaty powstały w okresie, gdy autor wyznawał naukę montanistów, którzy opowiadali się za skrajnym pacyfizmem ${ }^{14}$. Problem udziału chrześcijan w służbie wojskowej pojawił się niedługo potem w rozważaniach Orygenesa (ok. 185 - ok. 254) ${ }^{15}$. W rozprawie Contra Celsum ów autor poruszył kilka aspektów, które bezpośrednio dotyczyły żołnierskiego fachu ${ }^{16}$. Po pierwsze wyjaśnił, dlaczego chrześcijanie nie składają przysięgi lojalności wobec cesarza (sacramentum) ${ }^{17}$. Po drugie napisał, że chrześcijanie powinni być zwolnieni ze służby wojskowej tak samo, jak pogańscy kapłani. Uzasadniał swój pogląd tym, że chrześcijanie prowadzą walkę duchową i jako oręża używają modlitwy. Orygenes jednoznacznie sprzeciwiał się temu, by chrześcijanie brali czynny udział w walce i brukali krwią swoje dłonie. Nie widział jednak żadnej sprzeczności w tym, by modlili się w intencji walczącego władcy i jego armii, jeśli w ich przekonaniu

I.A. Richmond, The Roman Army and Roman Religion, „Bulletin of the John Rylands Library” 45 (1962) 185-197; M. Jaczynowska, Religie świata rzymskiego, Warszawa 1987, 156-160.

${ }^{12}$ Quintus Septymius Florens Tertullianus, De Idolatria 19, 1-3, ed. J.H. Waszink - J.C.M. Van Winden, Leiden - New York 1987, 59, tłum. K. Obrycki, w: Tertulian, Wybór pism III, PSP 65, Warszawa 2006, 147.

${ }^{13}$ Tenże, De corona 11, 1-7, ed. A. Kroymann, CCL 2, Turnhout 1954, 1039, tłum. T. Skibiński, PSP 65, 118-120.

${ }^{14}$ Poglądom Tertuliana na temat służby żołnierskiej poświęcono wiele miejsca w literaturze przedmiotu, por. E.A. Ryan, The Rejection of Military Service by the Early Christians, ThS 13 (1952) 17-20; W. Myszor, Chrześcijanie wobec świata. Problem wojny i pokoju w pierwotnym chrześcijaństwie, SSHT 16 (1983) 250; R. Stawinoga, Tertulian a świat antyczny, Kraków 2002, 8589; Minois, Kościól i wojna, s. 50-51; P. Veyne, Imperium grecko-rzymskie, tłum. P. Domański, Kęty 2008, 606. Informacje o życiu i nauce Tertuliana można odnaleźć u: H. Campenhausen, Ojcowie Kościoła, tłum. K. Wierszyłowski, Warszawa 1998, 147-169; Stawinoga, Tertulian, passim. Na temat montanizmu, por. M. Starowieyski, Montanizm, w: Encyklopedia Kultury Bizantyńskiej, red. O. Jurewicz, Warszawa 2002, 357; J. Słomka, Nowe proroctwo. Historia i doktryna montanizmu, SACh SN 4, Katowice 2007.

${ }^{15}$ Życie, działalność i nauczanie Orygenesa szczegółowo omówił Henri Crouzel (Orygenes, thum. J. Margański, Kraków 2004, 392). Por. też Campenhausen, Ojcowie Kościoła, s. 37-50.

${ }^{16}$ Por. Origenes, Contra Celsum, ed. M. Borret, SCh 132, 136, 147, 150 i 227, Paris 1967-1976, thum. S. Kalinkowski: Orygenes, Przeciw Celsusowi, Warszawa 1986.

${ }^{17}$ Por. tamże VIII 65, SCh 150, 232-234, tłum. Kalinkowski, s. 419; VIII 67, SCh 150, 328-330, thum. Kalinkowski, s. 420-421. 
wojna dotyczyła słusznej sprawy ${ }^{18}$. Inaczej tę kwestię pojmował Laktancjusz (ok. 250 - ok. 330), dla którego każda wojna stanowiła zbrodnię i który nie uznawał w tym przypadku żadnego wyjątku ${ }^{19}$. Poglądy wyżej wspomnianych autorów były jedynie postulatami etycznymi i nie stanowiły prawa kościelnego. Były wyrazem toczącej się dyskusji, próbą refleksji, jednakże w praktyce nie obowiązywały chrześcijan w życiu codziennym. Dla III w. istnieje reprezentatywny zbiór przepisów kościelnych, którego oddziaływanie na życie codzienne zaznaczyło się wśród wspólnot chrześcijańskich na Wschodzie i Zachodzie. Jest nim Tradycja Apostolska, której autorstwo przypisywano Hipolitowi Rzymskiemu (ok. 170-235) ${ }^{20}$. Znajdujące się w niej przepisy zawierają surowe wytyczne dotyczące służby wojskowej. Chrześcijaninowi nie wolno było składać przysięgi wojskowej (sacramentum), obowiązywał go stanowczy zakaz zabijania oraz pozostawania w służbie publicznej, w tym wojskowej. Za złamanie wymienionych przepisów przewidywano ekskomunikę ${ }^{21}$. Jednoznaczny rygoryzm Tradycji Apostolskiej mógł mieć swoje źródło w trudnej i złożonej sytuacji chrześcijan w Cesarstwie Rzymskim w III w. Okresy pokoju przeplatane prześladowaniami oraz pojawienie się nowych pogańskich form religijności mogły mieć wpływ na usztywnienie poglądów i stanowcze określenie postawy, jaką powinni zająć chrześcijanie wobec służby wojskowej i wojny ${ }^{22}$. Jednakże zawarte $\mathrm{w}$ dokumentach $\mathrm{z}$ tego okresu relacje dowodzą,

${ }^{18}$ Por. tamże VIII 73, SCh 150, 344-348, thum. Kalinkowski, s. 424-425.

${ }^{19}$ Por. Lactantius, Divinae institutiones VI 20, 15-17, ed. C. Ingremeau, SCh 509, Paris 2007, 316-318, thum. M. Masny, w: W. Myszor, Europa. Pierwotne chrześcijaństwo. Idee i życie społeczne chrześcijan (II i III wiek), Relectiones 7, Warszawa 1999/2000, 117.

${ }^{20}$ Tradycja Apostolska (Hippolytus Romanus, Traditio apostolica, ed. B. Botte, SCh 11 bis, Paris 1968) to zbiór przepisów o bardzo skomplikowanej historii. Dużo wskazuje na to, że jest kompilacją starszych tekstów różnego pochodzenia. W latach 70. ubiegłego wieku Jean Magne zakwestionował twierdzenie, że autorem Tradycji Apostolskiej jest Hipolit Rzymski. Marcel Metzger, wydawca francuskiej edycji Konstytucji Apostolskich (Les Constitutions Apostoliques, t. 1-3, ed. M. Metzger, SCh 320, 329 i 336, Paris 1985-1987) zgodził się z tezami J. Magne. Obecnie trudno jest jednoznacznie rozstrzygnać kwestię autorstwa, a argumenty za i przeciw spisaniu jej przez Hipolita są żywo dyskutowane wśród badaczy. Por. H. Pietras, Pośmiertna kariera św. Hipolita, VoxP 17 (1997) t. 32-33, 68; E. Wipszycka, Wprowadzenie do studiów nad instytucjami Kościoła w Egipcie późnoantycznym, w: Chrześcijaństwo u schyłku starożytności, red. T. Derda E. Wipszycka, t. 2, Warszawa 1999, 201-207; taż, Źródła normatywne kościelne, s. 311-316.

${ }^{21}$ Por. Traditio apostolica 16, SCh 11bis, 72-73, tłum. M. Michalski, w: Antologia literatury patrystycznej, t. 1, Warszawa 1975, 309 (Tradycja Apostolska II 2). Alan Kreider (Military Service, s. 418-425) przeanalizował kościelne przepisy z III w., które dotyczą stosunku chrześcijan wobec służby wojskowej i omówił treść 16. kanonu Tradycji Apostolskiej. Porównał przy tym różne wersje wspomnianego tekstu oraz odniósł się do zmian, jakie wprowadzili do niego późniejsi redaktorzy. Odwołał się także do najnowszych ustaleń dokonanych przez Paula Bradshawa, Maxwella Johnsona, Edwarda Philipsa i opublikowanych w dziele pt. The Apostolic Tradition: A Commentary, Minneapolis 2002.

${ }^{22}$ Złożoną sytuację chrześcijan w III w. na tle ówczesnej sytuacji politycznej wewnątrz Cesarstwa Rzymskiego przedstawiła Ewa Wipszycka w artykule Państwo rzymskie a chrześcijaństwo do 
że praktyka często mijała się z kościelnymi wymaganiami. Na przestrzeni II i III w. stosunkowo wielu chrześcijan służyło $\mathrm{w}$ armii ${ }^{23}$. Zajmowali oni różne postawy wobec kwestii sacramentum, kultu signum, czy zabijania wrogów w walce. Georges Minois podejrzewa, że z faktem wzrostu chrześcijan w armii na przełomie II i III w. Kościół po cichu się pogodził²4. Bieg spraw codziennych rządził się swoimi prawami. Konieczność obrony granic cesarstwa nie pozostawała przecież bez znaczenia także dla poczucia bezpieczeństwa chrześcijan. W okresach ,pokoju”, czyli w czasie pomiędzy prześladowaniami, biskupi dostrzegali konieczność uznawania autorytetu „sprawiedliwej” władzy $^{25}$. Dlatego niewykluczone, że wówczas niektórzy hierarchowie dawali chrześcijanom ciche przyzwolenie na odbywanie służby wojskowej. A. Kreider słusznie zauważa, że w tej sprawie dużą rolę odrywały również lokalne tradycje i wydarzenia. Jednakże uczony dalej podkreśla, że ich gruntowniejsze poznanie i zrozumienie, jak dalece wpływały na kształtowanie się kościelnego prawodawstwa, wymaga dalszych badań ${ }^{26}$.

2. Chrześcijańscy żołnierze $\mathbf{w}$ chrześcijańskim państwie. Na początku IV w. relacje Kościoła z państwem rzymskim nabrały nowego charakteru. Chrześcijaństwo zyskało protektora w osobie cesarza Konstantyna (ok. 272 - 22 V 337; cesarz od 25 VII 306). Oczywiście chrystianizacja Cesarstwa postępowała stopniowo i nie od razu po 313 r. możemy mówić o „chrześcijańskim cesarstwie". Jednakże był to moment przełomowy, od którego zaczęto promować religię chrześcijan wśród poddanych Konstantyna ${ }^{27}$. Z czasem wypracowano ideologię chrześcijańskiego państwa, w której założeniu było ono odbiciem Królestwa Bożego na ziemi ${ }^{28}$. W naturalny sposób, również armia

początków IV wieku, w: Starożytny Rzym we wspótczesnych badaniach. Państwo - Społeczeństwo - Gospodarka. Liber in memoriam Lodovici Piotrowicz, red. J. Wolski - T. Kotula - A. Kunisz, Kraków 1994, 172-185.

${ }^{23}$ Ukazują ten fakt różne relacje $\mathrm{z}$ tego okresu, np. opowiadanie o legionie meliteńskim z czasów Marka Aureliusza zawarte u Tertuliana (Apologeticum 5, 6, ed. H. Hoppe, CSEL 69, Vindobonae - Lipsiae 1939, 15, tłum. J. Sajdak: Tertulian, Apologetyk, POK 20, Poznań 1947, $25-$ 26) i poświadczone przez Euzebiusza z Cezarei (HE V 5, 1-2, ŹMT 70 [tekst grecko-polski, układ i oprac. H. Pietras, tłum. A. Caba na podstawie tłum. A. Lisieckiego], Kraków 2013, 320-321).

${ }^{24}$ Por. Minois, Kościót i wojna, s. 52.

${ }^{25}$ Około 272 r. w czasie tzw. „Małego Pokoju” biskupi odwołali się do cesarza Aureliana w sprawie herezjarchy Pawła z Samosaty. Por. J. Keller, Wczesny Kościót i jego organizacja, w: Katolicyzm starożytny jako forma rozwoju pierwotnego chrześcijaństwa, red. J. Keller, Warszawa 1969, 166; Wipszycka, Państwo rzymskie, s. 184-185. Na temat Pawła z Samosaty (ok. 200 - ok. 275) por. SWP 320-321.

${ }^{26}$ Por. Kreider, Military Service, s. 417 i 435.

${ }^{27} \mathrm{Na}$ temat nawrócenia Konstantyna i zmiany polityki państwa rzymskiego względem chrześcijan por. nota 1.

${ }^{28}$ Por. W. Ceran, Cesarz w politycznej teologii Euzebiusza z Cezarei i nauczaniu Jana Chryzostoma, „Acta Universitatis Lodziensis. Folia Historica” 44 (1992) 13-27; Minois, Kościót 
ulegała chrystianizacji, a stosunek Kościoła do służby wojskowej stawał się bardziej pozytywny.

W IV i V w. problem służby wojskowej, o czym pisałem na wstępie, był poruszany $\mathrm{w}$ dwóch grupach kościelnych źródeł. Pierwsza, to zbiory przepisów o charakterze pseudoepigraficznym, których autorstwo przypisywano apostołom lub ich bezpośrednim uczniom. Pierwotnie służyły one jedynie lokalnym wspólnotom, lecz w wyniku rozpowszechniania ich kopii, zaczęły oddziaływać na szerszy krąg chrześcijan. Szczególnym poważaniem cieszyły się we wschodniej części Imperium ${ }^{29}$. Druga, to postanowienia synodów i soborów, które na początku IV w. zaczęły stanowić powszechnie obowiązujące prawo kościelne ${ }^{30}$.

Najpierw prześledzimy przepisy zawarte $\mathrm{w}$ wybranych źródłach z pierwszej grupy. Należą do niej m.in. Canones Hippolyti (Kanony Hipolita) ${ }^{31}$. Jest to greckojęzyczny zbiór, który przypuszczalnie powstał w Egipcie, pomiędzy rokiem 336 a 340. Później został przetłumaczony na język koptyjski i arabski. Do naszych czasów przetrwała jedynie wersja arabska. Na treść zamieszczonych w nim przepisów ogromny wpływ wywarła recepcja Tradycji Apostolskiej, a zatem dzieła starszego o około sto lat. W VI w. wschodni kanoniści dołączyli Canones Hippolyti do ogólnego zbioru zatytułowanego Canones Patrum Graecorum ${ }^{32}$.

W kanonie 13. znajdujemy jednoznaczny przepis:

„Ten, kto otrzymał władzę zabijania, na przykład żołnierz, niech pod żadnym pozorem nie zabija, nawet jeśli otrzyma rozkaz zabicia $[\ldots]^{\prime 33}$.

W kanonie 14. autor idzie jeszcze dalej i przewiduje konkretne sankcje:

„Chrześcijanin nie powinien zostawać żołnierzem, chyba, że przymusi go zwierzchnik pod groźbą miecza. Niech nie nakłada na siebie grzechu krwi.

$i$ wojna, s. 58; F. Kolb, Ideat późnoantycznego władcy. Ideologia $i$ autoprezentacja, thum. A. Gierlińska, Poznań 2008, 55-90 i 130-145.

${ }^{29}$ Por. nota 5.

${ }^{30}$ Por. M. Starowieyski, Sobory Kościoła niepodzielonego, t. 1, Tarnów 1994; S. Bralewski, Imperatorzy późnego cesarstwa rzymskiego wobec zgromadzeń biskupów, Byzantina Lodziensia 1, Łódź 1997; K. Schatz, Sobory powszechne. Punkty zwrotne w historii Kościoła, tłum. J. Zakrzewski, Kraków 2002, 15-21.

31 Canones Hippolyti (versio arabica), ed. R.-G. Coquin, PO 31/2, Paris 1966, thum. J. Szymańczyk: Kanony Hipolita (wersja arabska), w: Kanony Ojców Greckich (tekst grecki i polski), Atanazego i Hipolita (tekst arabski i polski), ŹMT 49 (= SCL 3), Kraków 2009, 176-203.

$32 \mathrm{Na}$ temat miejsca i czasu powstania oraz charakterystyki Canones Hippolyti, por. R.-G. Coquin, Introduction, w: Les Canons d'Hippolyte, ed. tenże, PO 31/2, Paris 1966, 273338; Wipszycka, Wprowadzenie do studiów nad instytucjami Kościoła, s. 201 i 202; taż, Źródta normatywne kościelne, s. 312; Kreider, Military Service, s. 426.

${ }^{33}$ Canones Hippolyti (versio arabica) 13, PO 31/2, 366-367, SCL 3, 184. 
Gdy jednak przeleje krew, niech nie uczestniczy w tajemnicach, chyba, że po oczyszczeniu się przez odbycie kary, płacz i wzdychania. [...]"34.

Lata 336-340, na które według nowych ustaleń przypadło spisanie Canones Hippolyti, obfitowały w wiele dramatycznych wydarzeń. W Egipcie, gdzie powstały, arcybiskup Atanazy (ok. 295 - 2 V 373) toczył zacięte spory z melecjanami oraz zwolennikami arianizmu. Jedną ze stron konfliktu był cesarz Konstantyn, któremu zależało na religijnym pokoju w Imperium $^{35}$. Nie wiemy, czy Canones Hippolyti zostały napisane przez kogoś z otoczenia aleksandryjskiego patriarchy, czy też powstały w środowisku jednego ze zwalczanych przez niego ugrupowań. Tak naprawdę nie wiemy, czy wydarzenia związane ze schizmą melecjańską lub kontrowersją ariańską w ogóle odcisnęły jakiekolwiek piętno na treści tych przepisów. Canones Hippolyti surowo zabraniały chrześcijanom służenia w wojsku. Przewidywały jedynie możliwość wstąpienia do armii tylko wtedy, gdyby odmowa wiązała się z karą śmierci. Jednakże wówczas chrześcijańskiemu żołnierzowi nie wolno było nikogo zabić. Należy jednak zaznaczyć, że w stosunku do przepisów Tradycji Apostolskiej, na której autor się ewidentnie wzorował, zaszła znacząca zmiana. Za grzech przelania krwi przewidywano dla chrześcijańskiego żołnierza sankcję pokuty. Na jej czas miał być on wyłączony z udziału w Eucharystii, ale po jej odbyciu mógł ponownie uczestniczyć w tym sakramencie. Kanon 14. nie precyzował jednak długości odbywania kary. Było to zupełne novum, gdyż Tradycja Apostolska już w przypadku samego podjęcia przez chrześcijanina służby wojskowej karała ekskomuniką i nie wspominała ani o możliwości pokuty ani o powrocie do wspólnoty ${ }^{36}$.

Około 374 r. w sprawie wojny i służby wojskowej głos zabrał Bazyli Wielki (329 - 1 I 379) 37 . W liście do Amfilocha (ok. 340 - ok. 395), biskupa Ikonium, przedstawił swoje stanowisko w kwestiach dyscypliny i porządku kościelnego w postaci kanonów. W VI w. list ten dołączono do uznawanego na Wschodzie zbioru przepisów eklezjalnych Canones Patrum Graecorum ${ }^{38}$. Bazyli uznał w nim, że agresja wojskowa jest grzechem popełnionym z rozmysłem i postawił go na równi z trucicielstwem i aborcją. Do jego przyczyn zaliczył chciwość i chęć pozbycia się wrogów ${ }^{39}$. W kanonie 13. zaznaczył on, że wcześniej zabijania na wojnie nie uznawano za zabójstwo. Podkreślił, że

${ }^{34}$ Tamże 14, PO 31/2, 368-369, SCL 3, 184 i 185.

${ }^{35}$ Por. Early Egyptian Christianity from its origins to 451 C. E., ed. C.W. Griggs, Coptic Studies 2, Leiden - Köln 1991, 117-169; J. Gliściński, Wspótistotny Ojcu, Łódź 1992, 21-48.

${ }^{36}$ Por. Traditio apostolica 16, SCh 11bis, 72-73. Zob. Kreider, Military Servive, s. 426.

${ }^{37}$ Por. SWP 87-90.

${ }^{38}$ Basilius Caesariensis, Epistula 188, PG 32, 663-684, thum. S. Kalinkowski: Bazyli z Cezarei, Pierwszy list kanoniczny do Amfilocha, biskupa Ikonium, w: SCL 3, 32-41.

${ }^{39}$ Tamże 8, PG 32, 675-678, SCL 3, 37-38. 
wybaczano je „obrońcom cnoty i religii” ${ }^{40}$. Niewykluczone, że Bazyli odniósł się w tym miejscu do praktyki, jaką stosował Kościół na terenie Kapadocji w III w., kiedy godził się na obecność chrześcijan w armii. Wiemy, o czym pisałem powyżej, że mimo rygorystycznych kanonów Tradycji Apostolskiej, pod koniec III w. liczba chrześcijan w wojsku rzymskim sukcesywnie rosła ${ }^{41}$. W dalszej części omawianego kanonu Bazyli udzielał rady, by żołnierze, którzy splamili ręce krwią, powstrzymali się od przyjmowania komunii przez trzy lata ${ }^{42}$. Jego pogląd w tej sprawie, jest jednak daleki od rygoryzmu, który odnajdujemy w treści Canones Hippolyti. Możemy przypuszczać, że Bazyli podróżując około 360 r. po egipskich pustelniach mógł się zapoznać z treścią kanonów przypisywanych Hipolitowi. Złagodzone stanowisko Bazylego oraz stosunkowo krótki okres wyznaczonej pokuty pokazują kierunek, w którym powoli ewoluowały poglądy Ojców Kościoła na kwestię służby wojskowej. Konieczność obrony chrześcijańskiego państwa przed agresorami, których Bazyli określał terminem „mordercy”, sprawiała, że Kościół zaczynał w IV w. uznawać zabijanie napadającego wroga za naruszenie natury bardziej „,eremonialnej” niż moralnej. Tacy żołnierze nie mieli „czystych rąk” i dlatego nie mogli przystępować do Eucharystii, jednakże ich czynów nie stawiano już na równi z zabójstwem z premedytacją.

W tym samym stuleciu możemy zaobserwować zmianę nastawienia chrześcijan do problemu służby w armii na terenie zhellenizowanej Syrii. Reprezentatywny dla tego regionu zbiór przepisów zatytułowany Constitutiones apostolorum (Konstytucje Apostolskie) zawiera kilka ustępów, które to ukazują $^{43}$. Przy rozpatrywaniu ich treści należy mieć świadomość, że ten zbiór

${ }^{40}$ Tamże 13, PG 32, 681-682, SCL 3, 40.

${ }^{41}$ Por. nota 23 i 24.

${ }^{42}$ Por. Basilius Caesariensis, Epistula 188, 13, PG 32, 681-682, SCL 3, 40. Constantin Zuckerman (Armia, w: Świat Bizancjum. Cesarstwo Wschodniorzymskie 330-641, red. C. Morrisson, thum. A. Graboń, t. 1, Kraków 2007, 209) uważa, że wyegzekwowanie tego wymogu w praktyce było mało realne. Należy jednak podkreślić, że poddanie się takiej procedurze pokutnej było sprawą indywidualną. Ponadto Bazyli traktuje niniejszy nakaz, jako radę, której zapewne udzielano żołnierzom w sprzyjających okolicznościach, np. w czasie pokoju lub po zakończeniu służby.

${ }^{43}$ Constitutiones apostolorum, ed. M. Metzger, t. 1-3, SCh 320, 329, 336, Paris 1985-1987, tłum. S. Kalinkowski: Konstytucje apostolskie, w: Konstytucje apostolskie oraz Kanony Pamfilosa $z$ apostolskiego synodu $w$ Antiochii. Prawo kanoniczne świętych Apostołów. Kary świętych Apostołów dla upadtych. Euchologion Serapiona, ed. A. Baron - H. Pietras, ŹMT 42 (= SCL 2), Kraków 2007, 1-293. Na temat daty powstania Konstytucji apostolskich wciąż trwają liczne dyskusje. Precyzyjne określenie roku powstania zbioru jest niemożliwe. We francuskiej edycji Marcel Metzger (Introduction, w: Les Constitutions Apostoliques, t. 1, ed. M. Metzger, SCh 320, 54-62) udowadnia, że dzieło powstało najpóźniej ok. 380 r. w Antiochii lub jej okolicach. Podobny pogląd wyraża Jan Żelazny (Biskup ojcem. Zarys eklezjologii syryjskiej na podstawie Konstytucji Apostolskich, Kraków 2006, 32-34) oraz Marcel Simon (10 IV 1907 - 26 X 1986) (Cywilizacja wczesnego chrześcijaństwa, s. 293). Do ustaleń sztrasburskiego uczonego odwołuje się również Ewa Wipszycka (Źródła normatywne kościelne, s. 320). Natomiast redaktorzy polskiego wydania 
przepisów jest autorską kompilacją wcześniejszych dzieł o charakterze normatywnym i dlatego często zawiera anachroniczne fragmenty w stosunku do rzeczywistości IV wieku ${ }^{44}$. Autor wyjaśnia, że nie każde zabójstwo jest złe. Wyrządzeniem zła jest uśmiercenie niewinnego. Jeśli zaś przedstawiciele władzy zabijają przestępcę nie popełniają $\mathrm{zła}^{45}$. Idąc tropem tego rozumowania można było przyjać, że zabicie wroga podczas walki w obronie państwa nie jest zbrodnią. Dlatego autor bez zastrzeżeń mógł polecać modlitwę:

„Prosimy Cię także, Panie, w intencji króla i sprawujących władzę oraz całego wojska: daj, aby nasze sprawy toczyły się w pokoju"46.

Kościół mógł już również przyjmować od żołnierzy dary na potrzeby duchowieństwa i wspólnoty. Constitutiones apostolorum zakazywały biskupowi przyjęcia daru jedynie od żołnierza, który nie poprzestawał na żołdzie i uciskał ubogich $^{47}$. Być może ten zapis odnosi się do sytuacji, podczas której armia wymuszała na ludności zapewnienie zakwaterowania i wyszynku. Zjawisko to często występowało w wieku IV ${ }^{48}$. Ciekawy passus odnajdujemy w księdze VIII:

Arkadiusz Baron i Henryk Pietras (Wprowadzenie, w: SCL 2, XIII-XVII) w sposób zdystansowany skłaniają się ku opinii, że dzieło powstało w 2. poł. IV w., por. też A. Baron, Modele biskupa propagowane $w$ Antiochii $w$ czasach Jana Chryzostoma. Refleksja nad druga księga Konstytucji Apostolskich na tle kanonów synodu antiocheńskiego z 341 r., w: Czasy Jana Chryzostoma i jego pasterska pedagogia, red. N. Widok, Opolska Biblioteka Teologiczna 105, Opole 2008, 13-15). Joseph G. Müller (L'Ancien Testament dans l'ecclésiologie des Pères. Une lecture des Constitutions Apostoliques, Instrumenta Patristica et Mediaevalia 41, Turnhout 2004, 54-57) datuje powstanie Konstytucji pomiędzy rokiem 377-393.

${ }^{44}$ W treści Konstytucji apostolskich możemy odnaleźć fragmenty dużo starszych zbiorów norm kościelnych, takich jak Didascalia apostolorum, czy Didache oraz fragmenty modlitw żydowskich, postanowienia wybranych synodów i inne, por. Baron - Pietras, Wprowadzenie, s. XII; Żelazny, Biskup ojcem, s. 18-23; Wipszycka, Źródła normatywne kościelne, s. 318-319; Metzger, Introduction, w: SCh 320, 14-33. Zob. też K. Bihlmeyer-H. Tüchle, Historia Kościoła. Starożytność chrześcijańska, tłum. J. Klenowski, t. 1, Warszawa 1971, 390-391. Dzieło to było bardzo popularne wśród chrześcijan na Wschodzie. W założeniu zbiór ten miał posiadać uniwersalny charakter, dlatego autor (bądź autorzy) przypisał mu apostolską proweniencję. Kościół na Wschodzie przyjął jedynie wchodzące w skład jego VIII księgi Canones apostolorum. Natomiast Constitutiones apostolorum ostatecznie odrzucono, jako zbiór o charakterze apokryficznym. Postanowienie to przyjęto na synodzie Quinisextum w latach 691/692. Por. G. Dagron, Kościót bizantyński i chrześcijaństwo bizantyńskie między najazdami a ikonoklazmem (VII wiek - poczatek VIII wieku), w: Historia chrześcijaństwa. Biskupi, mnisi i cesarze 610-1054, red. J. Kłoczowski, tłum. M. Żurowska, t. 4, Warszawa 1999, 58, nota 204. Arkadiusz Baron (Modele biskupa, s. 16-18) przeanalizował różne motywacje, które mogły towarzyszyć wówczas ojcom synodalnym przy podejmowaniu tej decyzji. Por. też: Wipszycka, Źródła normatywne kościelne, s. 320.

${ }^{45}$ Por. Constitutiones apostolorum VII 2, 8, SCh 336, 28-29, SCL 2, 176.

${ }^{46}$ Tamże VIII 12, 42, SCh 336, 200-201, SCL 2, 245.

${ }^{47}$ Por. tamże IV 6, 5, SCh 329, 178-181, SCL 2, 100.

${ }^{48}$ Por. nota 10. 
„Jeśli zgłosi się żołnierz, należy go pouczyć, żeby nikogo nie krzywdził, lecz poprzestawał na swym żołdzie, jeśli wyrazi zgodę, należy go przyjąć, jeśli nie, odrzucić" ${ }^{49}$.

Cytowany kanon omawia sprawę przyjmowania nowych katechumenów do wspólnoty i wyraźnie odwołuje się do fragmentu Ewangelii według św. Łukasza $(3,14)^{50}$. Znajdujemy w nim istotne informacje. Żołnierz, który zostawał chrześcijaninem nie musiał porzucać swojej profesji. W przeciwieństwie do sportowców, fletnistów, gladiatorów, szynkarzy i wielu innych ${ }^{51}$. Nie wolno było mu natomiast kogokolwiek krzywdzić. Ten zakaz zapewne odnosił się do powszechnego wówczas procederu stosowania przemocy w celu zajmowania kwater, zdobywania żywności i ograbiania domów, na czym cierpiała miejscowa ludność. Nic jednak nie wskazuje na to, by dotyczył on zabijania w walce. Jeśli ten przepis rozpatrzymy w świetle wcześniejszych wywodów autora, to wyrządzeniem krzywdy (głównie krewnym ofiary) byłoby zabicie niewinnej osoby. Taką krzywdą nie byłoby natomiast uśmiercenie wroga, który napada na kraj i zagraża chrześcijańskiemu porządkowi. W moim przekonaniu, właśnie taką wymowę mają przepisy dotyczące służby wojskowej w Constitutiones apostolorum. Żołnierz będący chrześcijaninem mógł pełnić swoją służbę dla dobra ogółu ze spokojnym sumieniem.

Wśród źródeł normatywnych, o których wiemy, że znacząco oddziaływały na życie codzienne chrześcijan w IV i V w., znajdują się także Canones apostolorum (Kanony apostolskie) ${ }^{52}$. Jest to zbiór o mocno zawikłanej historii, który z czasem stał się częścią VIII księgi Constitutiones apostolorum. Niewykluczone, że obydwa zbiory miały tego samego autora i powstały mniej więcej w tym samym czasie. Zapewne pierwotnie Canones apostolorum stanowiły odrębny zbiór. Kościół na Wschodzie uznał w roku 692 ich apostolską proweniencję ${ }^{53}$. Badania krytyczne przeprowadzone na przełomie XIX i XX w. udokumentowały ich powstanie w 2 . poł. IV w. W interesującym nas temacie stosunku chrześcijan do służby wojskowej odnajdujemy w tym zbiorze tylko jeden przepis, który go bezpośrednio dotyczy. Jest to kanon 83:

„Biskupa, prezbitera lub diakona, który pełni funkcję wojskową i chce zatrzymać obydwa stanowiska - związane z władzą rzymską i służbę kościelną, należy złożyć z urzędu"s4.

${ }^{49}$ Constitutiones apostolorum VIII 32, 10, SCh 336, 238-239, SCL 2, 259.

${ }^{50}$ Por. Evangelium secundum Lucam 3, 14: „Interrogabant autem eum et milites dicentes: quid faciemus et nos? et ait illis: neminem concutiatis neque calumniam faciatis et contenti estote stipendiis vestris", ed. R. Gryson: Biblia sacra iuxta Vulgatam versionem, Stuttgart 19944 1611.

${ }^{51}$ Por. Constitutiones apostolorum VIII 32, 7-9, SCh 336, 236-239, SCL 2, 259.

${ }^{52}$ Canones apostolorum, SCh 336, 274-309, tłum. S. Kalinkowski: Kanony apostolskie, w: SCL 2, 273-293.

${ }^{53}$ Por. Wipszycka, Źródta normatywne kościelne, s. 317-318.

${ }^{54}$ Canones apostolorum 83, SCh 336, 306-307, SCL 2, 292. 
Niniejsze prawo było wyraźnym krokiem zmierzającym do oddzielenia posługi kapłańskiej od spraw świeckich, w tym od służby wojskowej ${ }^{55}$. Omówione dotychczas źródła normatywne nie stanowiły w IV i V w. prawa kościelnego sensu stricto, chociaż niewątpliwie ich autorzy pragnęli nadać im taki właśnie charakter. Należy pamiętać o tym, że znajdujące się w nich kanony były raczej ideałem, do którego należało zmierzać. Życie codzienne często rządziło się swoimi prawami i również w przypadku problemu służby wojskowej, często odbiegało od zapisanych zaleceń. Należy się jednak zgodzić z tym, że ukazują one problemy, z jakimi borykały się ówczesne wspólnoty. W pewnym stopniu pozwalają także odtworzyć życie codzienne chrześcijan w tym okresie. Musimy pamiętać, że dla czytelnika z IV i V w. były autentycznymi dziełami autorów wymienionych $\mathrm{w}$ ich nagłówkach i dlatego do ich lektury odnosił się zapewne z nabożnym szacunkiem. Nie wiemy jednak, w jakim stopniu te przepisy przyswoiła sobie hierarchia kościelna i jak dalece je egzekwowała. Możemy się jedynie domyślać, że duchowni dobrze znali ich treść, skoro je powielano w tak wielu kopiach i to w kilku językach, i dyskutowano o nich na soborze w roku 692. Mało jednak znajdujemy do nich odniesień w innych dokumentach. Nie były powszechnie cytowane. Jedynie Tradycja Apostolska oraz wybrane kanony zaczerpnięte z episkopalnej korespondencji znalazły wyraźne echo w innych pismach. Wiemy, że źródła te cieszyły się ogromnym autorytetem w lokalnych społecznościach na Wschodzie. Dlatego w ich treści znajdujemy duże różnice $\mathrm{w}$ omawianiu tych samych problemów. Na Zachodzie były słabo znane i zostały przyswojone w niewielkim stopniu ${ }^{56}$.

W IV i V w. znaczącą rolę w kościelnym procesie legislacyjnym odegrały synody i sobory oraz korelujące z ich postanowieniami ustawy cesarskie. Sprawa stosunku Kościoła do służby wojskowej była poruszana podczas obrad sporadycznie ${ }^{57}$.

W 314 r. został zwołany synod do Arles, na którym biskupi mieli się zająć sprawą donatyzmu ${ }^{58}$. Było to jedno z pierwszych zgromadzeń, które odbywało

${ }^{55}$ Por. Minois, Kościót i wojna, s. 60.

${ }^{56}$ Por. Wipszycka, Źródła normatywne kościelne, s. 302 i 305-306.

${ }^{57}$ W IV i V w. wiodącym tematem synodów i soborów kościelnych były kontrowersje doktrynalne. Kwestie dyscyplinarne w niewielkim stopniu pojawiały się w porządku obrad, por. R.P.C. Hanson, The Search for the Christian Doctrine of God. Arian Controversy 318-381, Edynburg 1988, passim; Gliściński, Wspótistotny Ojcu, passim; J.H.W.G. Liebeschuetz, Barbarians and Bishops. Army, Church, State in the Age of Arcadius and Chrysostom, Oxford 1992, 157-165; T.D. Barnes, Athanasius and Constantius. Theology and Politics in the Constantinian Empire, Cambridge (Mass.) 1993, 7181, 109-120 i 136-151; Starowieyski, Sobory Kościoła niepodzielonego, t. 1, passim; Bralewski, Imperatorzy późnego cesarstwa rzymskiego, passim; Schatz, Sobory powszechne, s. 15-66.

${ }^{58}$ Por. Epistula synodi Arelatensis ad Silvestrum papam, Mansi II 463-470, thum. A. Baron A. Caba: List synodu w Arles do papieża Sylwestra, w: Dokumenty synodów od 50 do 381 roku, ŹMT 37 (=SCL 1), Kraków 2006, 68-70; Canones ad Silvestrum, Mansi II 471-474, thum. A. Baron - A. Caba: Kanony do Sylwestra 3, w: SCL 1, 71-74; Canones adscripti synodo Arelatensi, Mansi II 474, thum. A. Baron - A. Caba: Kanony przypisywane synodowi w Arles z 314 r., w: SCL 1, 74. Na 
się już w nowej dla chrześcijan sytuacji prawnej. Jej pozytywne skutki początkowo odczuwali tylko chrześcijanie z zachodniej części Imperium, gdyż całe państwo zostało zjednoczone pod władzą Konstantyna dopiero dziesięć lat później ${ }^{59}$. Z postanowień synodu w Arles, w omawianym tu temacie, interesujący jest dla nas kanon 3:

„Uznano, żeby systematycznie unikających służby wojskowej odsuwać od komunii [Kościoła]".

W łacińskim tekście oryginału znajdujemy dodatkowe sformułowanie ,in pace”, czyli „,w czasie pokoju” ${ }^{60}$. Sam kanon, jak też informacja, że do dezercji mogło dochodzić w czasie pokoju, od dawna sprawiają badaczom wiele problemów interpretacyjnych i są zarzewiem żywej dyskusji ${ }^{61}$. W moim przekonaniu tego kanonu nie można rozpatrywać w oderwaniu od kontekstu wydarzeń, które towarzyszyły jego przyjęciu. W 314 r. Konstantyn posiadał władzę jedynie nad zachodnią częścią Imperium. Jego działania względem chrześcijan nie miały jeszcze uniwersalnego charakteru, lecz dotyczyły tylko tych, którzy zamieszkiwali jemu podległe terytorium. W odległej prowincji w Afryce Północnej, która tradycyjnie przynależała do zachodniej części cesarstwa, doszło do ostrego sporu kościelnego pomiędzy rygorystami, a zwolennikami Cecyliana (III/IV w.), biskupa Kartaginy. Schizma zagrażała pokojowi w prowincji, gdyż

temat donatyzmu, por. T.D. Barnes, The Beginnings of Donatism, JTS 26 (1975) 13-22; S. Bralewski, Czy cesarz Konstantyn Wielki zabiegat o kompromis z donatystami?, VoxP 20 (2000) t. 38-39, 427448; Drake, Constantine and the Bishops, s. 212-225.

${ }^{59}$ Pierwsze synody za panowania Konstantyna odbywały się wyłącznie na Zachodzie, gdyż tylko do tej części Imperium ograniczała się jego władza. W 324 r., gdy Konstantyn zwyciężył Licyniusza, jego władza objęła także wschodnią część cesarstwa. Por. M. Jaczynowska, Dzieje Imperium Romanum, Warszawa 1995, 408-412; Bralewski, Imperatorzy późnego cesarstwa rzymskiego, s. 23-24.

${ }^{60}$ Canones ad Silvestrum 3, Mansi II 471, SCL 1, 71. W cytowanym powyżej polskim thumaczeniu pominięto zwrot „w czasie pokoju”, który występuje w tekście oryginału: „De his qui arma proiciunt in pace, placuit abstineri eos a communione" - tamże.

${ }^{61}$ Carl J. v. Hefele (15 III 1808 - 5 VI 1893) (A History of the Christian Councils to the close of the Council of Nicaea A. D. 325, trans. W.R. Clark, Edynburg 1883, 185-186) uważał, że czas pokoju, o którym jest mowa w kanonie dotyczył zakończenia prześladowań i dlatego chrześcijanie uznali, że mogą w pełni służyć cesarzowi. Podobnego zdania był Antoni Młotek (Postawy i świadectwa, s. 168), który stwierdzał, że chrześcijanie z wdzięczności okazali daleko idącą chęć współpracy. Natomiast Marcel Simon (Cywilizacja wczesnego chrześcijaństwa, s. 379 i 380) poszedł jeszcze dalej, gdyż uznał, że teoretyczny antymilitaryzm Kościoła w momencie przyjęcia tego kanonu całkowicie znikł. Autor zauważył także, że prawdopodobnie w opinii biskupów unikanie służby wojskowej mogło wywoływać niepotrzebne zgorszenie. George Kalantzis (Ceasar and the Lamb. Early Christian Attitudes on War and Military Service, Eugene 2012, 188-189) uważa, że biskupi na synodzie w Arles trafnie rozpoznali zmieniający się charakter Imperium. Potwierdzeniem tego było usunięcie ze służby wojskowej kilku aspektów kultu pogańskiego. W przekonaniu Kalantzisa, kanon 3. wskazywał na znaczącą zmianę w stosunkach państwa rzymskiego i Kościoła oraz zapowiadał całkowicie chrześcijański charakter armii, co nastąpiło w roku 416. 
zawsze istniało duże prawdopodobieństwo wybuchu zamieszek. Konstantyn osobiście zaangażował się w rozstrzygnięcie tego sporu. Gdy kolejne podejmowane kroki zawiodły, cesarz zwołał synod do Arles. Joseph Vogt (23 VI 1895 - 14 VII 1986) słusznie zauważył, że to zgromadzenie stało się narzędziem polityki cesarskiej. Kanon 3. pozwalał Konstantynowi zapewnić sobie lojalność chrześcijańskich żołnierzy stacjonujących w Kartaginie. Żołnierze w czasie pokoju często pełnili funkcje porządkowe, a ich obecność była gwarancją pokoju w odległych prowincjach. Ostatecznie siły wojskowe interweniowały w Kartaginie i okolicach by zaprowadzić porządek ${ }^{62}$. Dlatego uważam, że kanon 3. został przyjęty przede wszystkim na potrzeby rozwiązania problemu donatystów.

W 325 r. cesarz Konstantyn panował już niepodzielnie nad całym Cesarstwem Rzymskim. Z powodu niepokojów, jakie w Kościele wzbudzała kontrowersja ariańska, postanowił zwołać zgromadzenie biskupów, które uzyskało rangę pierwszego soboru powszechnego. Jego obrady odbyły się w Nicei ${ }^{63}$. Przyjęto na nim kanon 12:

„Ci, którzy wezwani przez łaskę w pierwszym porywie entuzjazmu porzucili służbę wojskową, lecz następnie podobni do psów powracających do swych wymiocin (por. Prz 26, 11; 2P 2, 22), posunęli się nawet do dawania pieniędzy i prezentów, aby tylko uzyskać ponowne przyjęcie do wojska, muszą pozostawać przez trzy lata między pokutnikami słuchającymi, a potem czynić pokutę przez dziesięć lat. Należy się tym ludziom uważnie przyjrzeć i zbadać, jaka jest ich wola poprawy i sposób okazywania skruchy [...]"64.

Niniejszy przepis odnosi się do czasu rywalizacji Konstantyna z Licyniuszem (ok 265-325). Około 320 r. Licyniusz zaczął podejmować jawnie antychrześcijańskie działania. Usuwał chrześcijan z administracji i armii, a faworyzował pogan. Popierał także kulty pogańskie, co dla wielu chrześcijan stanowiło ogromną próbę lojalności wobec swoich zasad. Dlatego wielu powodowanych gorliwością i trwaniem przy swojej wierze, opuściło szeregi armii Licyniusza. Być może niektórzy z nich zdecydowali się nawet zwolnić z intratnych państwowych posad. Niewykluczone, że po pewnym czasie pożałowali jednak swojej decyzji i zapragnęli powrotu do dawnej pozycji. Oczywiście wiązało się to ze sprzeniewierzeniem swojej religii. Oni jednak nie tylko pogodzili się z tym faktem, lecz gotowi byli za to zapłacić pieniędzmi lub podarunkami. Gdy zaś Konstantyn pokonał Licyniusza znów zapragnęli powrócić do Kościoła $^{65}$. Z tego powodu ojcowie soborowi nakazali surową, trwającą wiele lat

${ }^{62}$ Por. J. Vogt, Upadek Rzymu, tłum. A. Łukaszewicz, Warszawa 1993, 103-105.

${ }^{63}$ Por. Concilium Nicaenum (325), Mansi II 665-704, thum. T. Wnętrzak: Sobór Nicejski I (325). Kanony, w: Dokumenty Soborów Powszechnych. Tekst grecki, łaciński, polski, t. 1: (325-787), ŹMT 24 (= DSP 1), Kraków 2002, 27-47.

${ }^{64}$ Tamże 12, Mansi II 673-674, DSP 1, 37-39.

${ }^{65}$ Interpretacja, którą pod koniec lat pięćdziesiątych XX w. zaproponował Jean Gaudemet (10 IX 1908 - 17 V 2001), wydaje się spójna i nadal aktualna. Do jego ustaleń odwołuje się obecnie 
pokutę. W ten sposób uzyskiwano pewność, co do ich intencji.

Do kwestii służby wojskowej powrócono wiele lat później na synodzie rzymskim w $385 \mathrm{r}$. Jego postanowienia znamy z listu, jaki wystosował papież Syrycjusz (ok. 334 - 26 XI 399; papież od 17 XII 384) do Himeriusza (IV w.), biskupa hiszpańskiej Tarragony ${ }^{66}$. W zawartym w nim kanonie 5. czytamy:

„O tych zaś jakże stosownie uznała twoja Miłość, że trzeba się naradzić, którzy odbywszy pokutę, jak psy i świnie powracając do dawnych wymiocin i błota, ponownie zapragnęli i pasa służby wojskowej i przyjemności, rozrywek i nowych małżeństw i zabronionych kontaktów seksualnych [...] uważaliśmy, że należy postanowić, żeby wewnątrz Kościoła łączyli się z wiernymi jedynie w modlitwie [...], a od uczty stołu pańskiego byli oddzieleni. [...]"67.

Niniejszy kanon nie wypowiada się przeciwko udziałowi chrześcijan w służbie wojskowej. Biskup Rzymu poruszył w nim kwestię skutków złamania zakazów, jakie obowiązywały chrześcijan odbywających pokutę publiczną. Surowa praktyka, którą przyjęto na Zachodzie, zakazywała podczas publicznej pokuty zawierania małżeństwa, odbywania stosunków seksualnych oraz służby w wojsku. Penitent mógł ją odbyć tylko raz w życiu, a rygory z nią związane

Georges Minois (Kościół i wojna, s. 59). W moim przekonaniu ks. Henryk Pietras (Sobór Nicejski (325). Kontekst religijny i polityczny. Dokumenty. Komentarze, Myśl Teologiczna 74, Kraków 2013, 156-157) pomylił się pisząc, że ów kanon dotyczy tych, którzy odeszli z Kościoła dla kariery wojskowej. Z treści kanonu wyraźnie wynika, że odeszli z armii z powodu wiary, lecz później zapragnęli do niej wrócić. Gdy zestawi się to postanowienie z wcześniejszym kanonem 11., można jednoznacznie wywnioskować, że opisywany tu przypadek dotyczył wydarzeń z okresu tyranii Licyniusza. Odejście wspomnianych tu chrześcijan z armii, musiało się wiązać z pogańskimi praktykami, które nadal preferowano $\mathrm{w}$ armii Licyniusza oraz z szykanowaniem przez niego chrześcijan. Dlatego chęć powrotu w jej szeregi określono tu, jako „powrót do swych wymiocin”. Por. Eusebius Caesariensis, HE X 8, 1-2. 9, ŹMT 70, 692-695. Por. też Simon, Cywilizacja wczesnego chrześcijaństwa, s. 223 i 224. W tym okresie, o czym pisałem powyżej, pozostawanie w armii po nawróceniu nie było już dezawuowane. Konstantyn dokonał niezbędnych zmian, by chrześcijanie w armii nie musieli kalać się pogańskimi praktykami. Zmienił treść sacramentum, tak by chrześcijańscy żołnierze przysięgając nie odnosili się do imion pogańskich bogów (por. Vegetius Renatus, Epitoma rei militaris II 5, rec. K. Lang, Lipsiae 1869, 37-38). Ustanowił niedzielę dniem odpoczynku i modlitwy. Chrześcijańscy żołnierze mogli uczestniczyć w nabożeństwie, a pogańskim nakazano odmawianie modlitwy za miastem do Najwyższego Boga. Na tarczach i sztandarach nakazał umieścić chrześcijańskie labarum. Por. Eusebius Caesariensis, Vita Constantini IV 18-21, PG 20, 1165-1168, thum. Wnętrzak: Euzebiusz z Cezarei, Życie Konstantyna, ŹMT 44, Kraków 2007, 218-220; CTh II 8, 1; Aföldi, The Conversion, s. 89 i 90; Simon, Cywilizacja wczesnego chrześcijaństwa, s. 225; Minois, Kościót $i$ wojna, s. 59; Drake, Constantin and the Bishops, s. 185186; Bralewski, Życie religijne mieszkańców Konstantynopola, s. 412-414.

${ }^{66}$ Por. Epistula Siricii Himerio Tarraconensi episcopo, PL 13, 1131-1147, thum. A. Caba: List Syrycjusza do Himeriusza, biskupa Tarragony, w: Dokumenty synodów od 381 do 431 roku, ŹMT 52 (= SCL 4), Kraków 2010, 35-43. Na temat działalności papieża Syrycjusza, por. J.N.D. Kelly, Encyklopedia papieży, tłum. T. Szafrański, Warszawa 2006, 55-57.

${ }^{67}$ Epistula Siricii Himerio Tarraconensi episcopo 5, PL 13, 1137, SCL 4, 37-38. 
obowiązywały go do końca życia ${ }^{68}$. W 386 r. synod w Rzymie postanowił: „jeśli ktoś po odpuszczeniu grzechów zaciagnnąłby się do wojska, nie może zostać duchownym"69.

Treść tego przepisu znamy z listu papieża Syrycjusza do afrykańskich biskupów. Potwierdzał on zasadę oddzielania świętej służby od spraw świeckich, stosowaną od pewnego już czasu na Wschodzie, o której czytamy w Canones apostolorum $^{70}$. Kolejne zachodnie synody także ją sankcjonowały. W 8. kanonie, przyjętym przez biskupów w $400 \mathrm{r}$. na synodzie w Toledo, nakazywano:

„Jeśliby ktoś po chrzcie służył w wojsku i nosił chlamidę albo pas wojskowy, nawet jeśli nie popełniłby ciężkich grzechów, gdyby został dopuszczony do stanu duchownego, niech nie otrzyma godności diakona" ${ }^{\text {"71 }}$.

Hiszpański synod nie deprecjonował obecności chrześcijan w armii. Jednakże wyższe święcenia duchowne zastrzegał dla osób, które po chrzcie wyłącznie poświęciły się służbie bożej i nie splamiły się żadnym ciężkim grzechem. Ciekawe, że ojcowie synodalni zezwalali tym, którzy po chrzcie przez jakiś czas służyli w wojsku, aby w Kościele pełnili funkcje pomocnicze, zarezerwowane dla niższego duchowieństwa (np. lektora, odźwiernego). Jedynym warunkiem było sumienie wolne od ciężkiego grzechu. Osiemnaście lat później, synod w Telepte całkowicie zabronił wszystkim, którzy po chrzcie podjęli się służby wojskowej, by wstępowali w szeregi duchowieństwa ${ }^{72}$. W tej decyzji możemy dostrzec odwołanie się do postanowień synodu rzymskiego z 386 r., zwołanego za pontyfikatu papieża Syrycjusza.

${ }^{68}$ Szczególnie surowe zasady pokuty publicznej obowiązywały na Zachodzie w Galii i Hiszpanii, por. M. Gosselin, Power of the Pope during the Middle Ages, thum. M. Kelly, vol. 2, London 1853, 67-87; O.D. Watkins, A History of Penance: being a Study of Authorities, vol. 1: The Whole Church to A.D. 450, London 1920, 453-457. Na temat rozwoju praktyki pokutnej na Wschodzie i Zachodzie oraz dotyczących jej przepisów, por. Watkins, A History of Penance, vol. 1, passim; M. Sieniatycki, Spory na Zachodzie o dyscypline pokutna, PT 4 (1922) 273-301; J.N.D. Kelly, Poczatki doktryny chrześcijańskiej, tłum. J. Mrukówna, Warszawa 1988, 165-168 i 323-326; H. Krzysteczko, Od publicznej praktyki pokutnej do spowiedzi prywatnej, SSHT 29 (1996) 323-334; M. Chłopowiec, Pokuta w dokumentach synodalnych chrześcijańskiej starożytności, VoxP 30 (2010) t. 55, 121134; tenże, Teologia pokuty pierwszych wieków chrześcijaństwa w Kościele Wschodnim, „Roczniki Teologii Moralnej” 3 (2011) 131-152.

${ }^{69}$ Canones ex epistula Siricii ad episcopos Africanos 3, PL 13, 1158-1159, thum. A. Caba: Kanony z listu papieża Syrycjusza do biskupów Afryki 3, SCL 4, 46.

${ }^{70}$ Por. nota 53.

${ }^{71}$ Constitutio Concilii Toletani (A. D. 397-400) 8, PL 84, 330, thum. A. Caba: Konstytucja pierwszego synodu w Toledo (397-400) 8, SCL 4, 122.

${ }^{72}$ Por. Concilium Teleptense post consulatum gloriosissimi Honori XI et Constantii secundo VIII kalendas martias 3, PL 84, 237, tłum. S. Poręba: Synod Theleński po jedenastym konsulacie najdostojniejszego Honoriusza i drugim Konstancjusza, 24 lutego 3, SCL 4, 243. 
W 458 r. papież Leon Wielki (ok. 400 - 10 XI 461; papież od 29 IX 440), odpowiadając na pytania biskupa Rustyka (V w.) z Narbonne, napisał:

„Wstępowanie do wojska po spełnieniu pokuty jest przeciwne zasadom Kościoła, ponieważ mówi Apostoł: «Nikt, kto walczy dla Boga, nie wikła się w sprawy świeckie» $(2 \mathrm{Tm} 2,4)$. Dlatego ten, kto chce walczyć w wojsku, nie jest wolny od zasadzek diabła"73.

W przytoczonym liście papież Leon kategorycznie sprzeciwiał się łamaniu zasad związanych z przestrzeganiem rygorów publicznej pokuty ${ }^{74}$. Zgodnie z tym, o czym napisałem powyżej, przyjęta na Zachodzie praktyka publicznej pokuty wiązała się m.in. z dożywotnim porzuceniem służby w armiii ${ }^{75}$. W dalszej części omawianego listu biskup Rzymu nakazał mnichom, którzy porzucili stan konsekrowany dla służby wojskowej lub małżeństwa, aby odbyli publiczną pokutę, gdyż dopuścili się grzechu ${ }^{76}$. Oznaczało to natychmiastowe opuszczenie armii lub powstrzymanie się od współżycia ze współmałżonkiem. Wytyczne papieża Leona były kontestowane głównie przez biskupów na Zachodzie. Później zostały dołączone do zbioru dokumentów normatywnych w tzw. Decretum Gratiani, który stał się zalążkiem rzymskiego kodeksu prawa kanonicznego ${ }^{77}$.

Postanowienia synodów i soborów od początku IV w. w bezpośredni sposób kształtowały prawo kościelne. Ustanawiane podczas tych zgromadzeń przepisy były ważnym punktem odniesienia w życiu codziennym chrześcijan tego okresu. Temat służby wojskowej raczej nie pojawiał się na obradach synodów we wschodnich prowincjach. Wynikało to z faktu, że na tym obszarze dominowały problemy natury doktrynalnej. Biskupi na Wschodzie borykali się z kontrowersjami chrystologicznymi, które rujnowały jedność Kościoła, i głównie na nich koncentrowali swoją uwagę podczas synodów i soborów ${ }^{78}$. W sprawie służby wojskowej wschodni biskupi odwoływali się głównie do tradycji. Niewykluczone, że przy tej okazji odnosili się do treści zacytowanych powyżej dzieł o charakterze pseudoepigraficznym. Zaś poglądy na temat stosunku do armii wymieniali między sobą w korespondencji. Natomiast na Zachodzie poświęcano więcej uwagi problemom natury dyscyplinarnej.

${ }^{73}$ Leo Magnus, Epistula 167, 12, PL 54, 1206-1207, thum. B. Frontczak, w: Dokumenty synodów od 431 do 504 roku, ŹMT 62 (= SCL 6), Kraków 2011, 228.

${ }^{74}$ Por. D. Bachrach, Religion and the Conduct of War c. 300 - c. 1215, Woodbridge - Rochester N.Y. 2003, 26-27.

${ }^{75}$ Por. nota 66.

${ }^{76}$ Leo Magnus, Epistula 167, 14, PL 54, 1207, SCL 6, 229.

${ }^{77} \mathrm{Na}$ temat działalności mnicha Gracjana, por. G. Ghirlanda, Wprowadzenie do prawa kościelnego, tłum. S. Kobiałka, Myśl Teologiczna 8, Kraków 1996, 61-62; A. Winroth, The Making of Gratian's Decretum, Cambridge 2009, 1-33. Na temat procesu tworzenia prawa kanonicznego na Wschodzie, por. B. Flusin, Struktury Kościoła cesarskiego, w: Świat Bizancjum, t. 1, s. 166-167.

${ }^{78}$ Por. Gliściński, Wspótistotny Ojcu, passim; Wipszycka, Kościót Kościót w świecie późnego antyku, s. 178-253. 
Dlatego podczas synodów problem służby wojskowej pojawiał się w dwóch aspektach: publicznej pokuty oraz możliwości pogodzenia posługi kościelnej z zawodem żołnierza. Należy podkreślić, że dla postanowień biskupów w zachodnich prowincjach ogromną rolę odgrywał autorytet biskupa Rzymu ${ }^{79}$.

$$
* * *
$$

Wraz z dekretem cesarskim ogłoszonym w 416 r., za panowania Honoriusza (9 XII 384 - 15 VIII 423; cesarz od 17 I 395) na Zachodzie i Teodozjusza II (10 IV 401 - 28 VII 450; cesarz od 1 V 408) na Wschodzie, armia rzymska nabierała $\mathrm{w}$ pełni chrześcijańskiego charakteru ${ }^{80}$. W ten sposób z prawnego punktu widzenia zakończył się długofalowy proces chrystianizacji aparatu państwowego, do którego należało również wojsko. Na przykładzie wybranych kościelnych źródeł normatywnych mogliśmy prześledzić ewoluowanie poglądów hierarchii duchownej na kwestię obecności chrześcijan w armii. Po zapoznaniu się $\mathrm{z}$ ich treścią zauważamy, że ten proces przebiegał $\mathrm{w}$ sposób zróżnicowany we wschodnich i zachodnich prowincjach Imperium.

Chrześcijanie byli obecni w armii rzymskiej już w III w. Pogański charakter oraz przelewanie krwi podczas walk budzily w środowisku apologetów i hierarchów kościelnych duży opór przed zezwalaniem chrześcijanom na pełnienie służby wojskowej. Dlatego w kościelnych przepisach z III w. odnajdujemy stanowczy zakaz wstępowania do armii lub kontynuowania tej służby po przyjęciu do wspólnoty. $Z$ dokumentów innej proweniencji dowiadujemy się jednak, że liczba chrześcijan $w$ armii stale wzrastała. Wielu z nich godziło służbę w wojsku ze swoim sumieniem, nie stosując się do wspomnianych zakazów.

$\mathrm{Na}$ początku IV w. cesarz Konstantyn obdarował chrześcijan swobodą religijną. Zezwolił na to, aby chrześcijańscy żołnierze przy składaniu przysięgi wojskowej (sacramentum) nie odwoływali się już do pogańskich bogów i by mogli uczestniczyć w niedzielnych nabożeństwach. Cesarstwo powoli stawało się państwem chrześcijańskim. Dlatego w przepisach kościelnych z IV i V w.

${ }^{79}$ Por. S. Bralewski, Obraz papiestwa w historiografii kościelnej wczesnego Bizancjum, Byzantina Lodziensia 10, Łódź 2006, 9-14.

${ }^{80}$ Por. CTh XVI 10, 21, ed. C. Pharr, London 1952, 475-476, thum. A. Caba: Kodeks Teodozjusza. Księa Szesnasta, ŹMT 71 (= SCL 7), Kraków 2014, 122. Niniejszy dekret zakazywał poganom pełnienia jakiejkolwiek formy służby publicznej, do której m.in. należała służba w armii. Wydanie tego dekretu nastąpiło, gdy na dworze w Konstantynopolu zaostrzono antypogańską politykę. Niewykluczone, że inspiratorem tego dekretu był praefectus pretorio Aurelian, który z racji pełnionego urzędu mógł mieć duży wpływ na decyzje nastoletniego Teodozjusza II, por. K.G. Holum, Theodosian Empress. Women and Imperial Dominion in Late Antiquity, The Transformation of the Classical Heritage 3, Berkeley - London 1982, 98-100; Liebeschuetz, Barbarians and Bishops, s. 146-153. Oczywiście samo wydanie dekretu nie rozwiązało od razu problemu obecności pogan w aparacie państwowym, niemniej jednak wiele wskazuje na to, że pozbyto się ich z najbliższego otoczenia cesarza, por. Chuvin, Ostatni poganie, s. 110-115. 
znajdujemy akceptację dla obecności chrześcijan w armii. Mimo że zabijanie wroga było obarczone koniecznością odbycia pokuty, to jednak nie niosło już za sobą kary ekskomuniki, bez możliwości powrotu do wspólnoty ${ }^{81}$. Kościół oczekiwał, że chrześcijańscy żołnierze będą się zadowalać wyłącznie żołdem i nie będą krzywdzić innych poprzez kradzieże, wymuszanie kwater, czy zabieranie żywności. Kościół na Wschodzie nie widział już nic złego w przyjmowaniu od nich darów na utrzymanie duchowieństwa i ubogich, jeśli prowadzili się bez zarzutu.

W połowie IV w. rozpoczęło się oddzielanie posługi duchownych od pełnienia świeckich obowiązków. Dlatego biskupi w obydwu częściach cesarstwa uznali, że duchowni nie mogą służyć w wojsku. Na Zachodzie, wierni, którzy wstąpili do armii po przyjęciu chrztu, nie mogli w przyszłości otrzymać święceń kapłańskich. Na Wschodzie nie podchodzono do tej sprawy aż tak rygorystycznie, o czym świadczy chociażby przypadek Nektariusza (zm. 17 IX 397), biskupa Konstantynopola (od 381) ${ }^{82}$. Pod koniec IV w. na Zachodzie przyjęto bardzo surowe zasady publicznej pokuty. Papieże przypominali w listach do biskupów diecezji w Hiszpanii i Galii, że po odbyciu tej generalnej pokuty powrót do armii był dożywotnio zabroniony.

Nie możemy zapominać, że na zmianę stosunku Kościoła do służby wojskowej wpłynęły także uwarunkowania polityczno-militarne cesarstwa. W IV i V w. jego granice były notorycznie nękane najazdami barbarzyńców i zagrożone ze strony Persji ${ }^{83}$. Pamiętajmy przy tym, że w omawianym okresie armia nie cieszyła się w rzymskim społeczeństwie popularnością ${ }^{84}$. Dlatego ewoluujące stanowisko Kościoła musiało być przychylnie przyjmowane przez

${ }^{81}$ Bazyli Wielki przewidywał w tym wypadku tylko trzyletnią pokutę. Por. nota 38.

${ }^{82}$ J.N.D. Kelly, Złote usta. Jan Chryzostom - asceta, kaznodzieja, biskup, thum. K. Krakowczyk, Bydgoszcz 2001, 115-116.

${ }^{83}$ Zagrożenia militarne granic we wschodniej i zachodniej części cesarstwa w IV i V w. zostały dokładnie omówione w ogromnej liczbie publikacji. Dlatego z konieczności przywołuję tylko kilka wybranych, por. Liebeschuetz, Barbarians and Bishops, s. 7-145; A. Cameron, Późne cesarstwo rzymskie, tłum. M. Kwiecień, Warszawa 1993, 157-176; L.A. Tyszkiewicz, Hunowie w Europie. Ich wplyw na Cesarstwo Wschodnie i Zachodnie oraz ludy barbarzyńskie, Wrocław 2004, passim; P. Heather, Upadek cesarstwa rzymskiego, thum. J. Szczepański, Poznań 2006, passim; M. Pawlak, Aecjusz i barbarzyńcy, Kraków 2009, passim; P. Heather, Imperia i barbarzyńcy. Migracje i narodziny Europy, tłum. J. Szczepański, Poznań 2010, 54-292.

${ }^{84}$ Armia nie cieszyła się popularnością w społeczeństwie rzymskim już na początku IV wieku. Wówczas wojsko często interweniowało podczas rozruchów, które wybuchały w prowincjach na tle kontrowersji ariańskiej, por. M.B. Leszka, Udziat sit zbrojnych w procesie odsuwania od władzy biskupów aleksandryjskich podczas kontrowersji ariańskiej na Wschodzie, VoxP 19 (1999) t. 3637, 349-365. Adam Ziółkowski (Historia Rzymu, Poznań 2008, 566-568) upatruje dodatkowych przyczyn tego negatywnego postrzegania armii w jej postępującej barbaryzacji. W IV i V w. młodzi Rzymianie masowo uchylali się od podejmowania służby wojskowej. Tymczasem szeregi rzymskich legionów zasilali osiedlający się w granicach cesarstwa barbarzyńcy, którzy podkreślali swoją odrębność. Z czasem pojawili się w elitarnych jednostkach i byli forowani przez cesarzy, 
cesarzy i elity rządzące. Na początku V w. sytuacja stała się dramatyczna, gdyż do Rzymu wdarli się barbarzyńcy. Rozwój wypadków skłonił duchownych na Zachodzie do pogłębienia refleksji nad koniecznością prowadzenia wojen i zabijania wrogów. Należał do nich św. Augustyn (13 XI 354 - 28 VIII 430), w którego wywodach możemy znaleźć uzasadnienie dla tzw. wojny sprawiedliwej ${ }^{85}$. Natomiast na Wschodzie zaczął przeważać pogląd, że wojny wygrywa się tylko z Bożą pomocą ${ }^{86}$.

\section{SOLDIERS AND MILITARY SERVICE IN THE LIGHT OF LEGISLATIVE CHURCH SOURCES FROM THE FOURTH AND FIFTH CENTURIES}

\section{(Summary)}

At the beginning of the fourth century the legal situation of Christians in the Roman Empire changed dramatically. Thanks to the Emperor Constantine they were no longer persecuted, and their faith became religio licita. From that point onwards the views of Christians on the state began to evolve. It was a long-term process, and happened at a varied pace. One of the aspects of this transformation was the change of Christian attitude to military service. It needs to be said that, from this perspective, the Church legislative sources have not been examined in a great detail. This article aims to take a closer look at several of the sources that include Church regulations relating to military service of the fourth and fifth centuries. These include, i.a., Canons of Hippolytus; Letters of St. Basil; Apostolic Constitutions and Canons of the Apostles. In addition, the article discusses the relevant contents of synodal and council canons from said period. These regulations show the adaptation of Church legislature to the new circumstances, in which the Roman state stopped being the persecutor and became the protector of Christianity.

The analysis of numerous documents confirms that Christians were present in the Roman army already in the third century. Because of the spilling of blood and the pagan rites performed in the army, the Church hierarchs strongly resisted the idea of allowing Christians to serve in the military. Church regulations from the third century strictly forbade enlisting in the army, or continuing military service

\footnotetext{
por. A. Hamman, Życie codzienne w Afryce Pótnocnej w czasach św. Augustyna, thum. M. StafiejWróblewska - E. Sieradzińska, Warszawa 1989, 388-392.

${ }^{85}$ Poglądy św. Augustyna na temat służby w wojsku i wojny są obszernie omówione w literaturze przedmiotu. Dlatego odsyłam do kilku wybranych publikacji, por. J. Śrutwa, Chrześcijanie w stużbie tego świata. Wizja Tertuliana $i$ św. Augustyna, w: Chrześcijanie a życie publiczne $w$ Cesarstwie Rzymskim III-V w., red. tenże, Lublin 1988, 71-94; Hamman, Życie codzienne w Afryce Pólnocnej, s. 390-392; Minois, Kościót i wojna, s. 62-71; J.M. Mattox, Saint Augustine and the Theory of Just War, London - New York 2006, passim; I. Precz, Czy wojna może być sprawiedliwa? Rzymskie inspiracje św. Augustyna, w: Apud Patres. Prawo rzymskie w literaturze wczesnochrześcijańskiej, red. A. Dębnicki - M. Wójcik, Lublin 2011, 121-132.

${ }^{86}$ Por. Zuckerman, Armia, s. 209-210.
} 
for those who were newly accepted into the community, for the reasons mentioned above. From other documents, however, we learn that the number of Christians in the army was nonetheless increasing. Many were able to reconcile military service with their conscience.

At the beginning of the fourth century emperor Constantine granted Christians religious freedom. He allowed Christian soldiers to abstain from invoking pagan gods while swearing military oath (sacramentum), and to participate in Sunday services. The empire was slowly becoming a Christian state. It is for this reason that in the Church regulations from the fourth and fifth century we find acceptance for the presence of Christians in the army. Even though killing of an enemy required undertaking penance, it was no longer a reason for excommunication with no possibility of returning to the Christian communion. The Church expected Christian soldiers to be satisfied with their wages alone, and to avoid harming others through stealing, forced lodging or taking food. The Church in the East no longer considered it wrong to accept gifts for the upkeep of clergy and other faithful from the soldiers who behaved in a correct manner. From the mid-fourth century performing religious services started being treated as separate from performing a layperson's duties. For this reason the bishops, in both parts of the empire, decided that clergy are barred from military service. In the West, those of the faithful who enlisted with the army after being baptised could no longer be consecrated in the future. In the East, the approach was less rigorous, as the case of Nectarius, the Archbishop of Constantinople, shows. By the end of the fourth century, the West adopted very strict rules of public penance for soldiers - the Popes reminded in their letters to the bishops in Spain and Gaul that after performing the public penance, the soldiers were forbidden to return to the army.

We should not forget that the change in the attitude of the Church to military service was also affected by the political-military situation of the Empire. During the fourth and fifth centuries its borderlands were persistently harassed by barbarian raids, and the Persian border was threatened. Let us also remember that the army was not popular in the Roman society during this period. For these reasons, the shifting position of the Church had to be positively seen by the Empire's ruling elites. The situation became dramatic at the beginning of the fifth century, when Rome was sacked by barbarians. Developing events caused the clergy to deepen their reflections on the necessity of waging war and killing enemies. Among such clergymen was St. Augustine, in whose writings we may find a justification of the so-called just war. Meanwhile, in the East, the view that wars can be won only with God's help began to dominate.

Key words: Christian soldier, military service, Church regulations, Canons of Hippolytus, Letters of St. Basil, Apostolic Constitutions, Canons of the Apostles.

Słowa kluczowe: chrześcijański żołnierz, służba wojskowa, przepisy kościelne, Kanony Hipolita, Listy św. Bazylego, Konstytucje apostolskie, Kanony apostolskie. 
